ARTICLE

https://doi.org/10.1038/s41467-019-10304-y

\title{
Selective light absorber-assisted single nickel atom catalysts for ambient sunlight-driven $\mathrm{CO}_{2}$ methanation
}

\author{
Yaguang Li (i) 1,8, Jianchao Hao ${ }^{1,8}$, Hui Song ${ }^{2,3,8}$, Fengyu Zhang ${ }^{1}$, Xianhua Bai ${ }^{1}$, Xianguang Meng ${ }^{4}$, \\ Hongyuan Zhang ${ }^{5}$, Shufang Wang ${ }^{1}$, Yong Hu (i) ${ }^{5} \&$ Jinhua Ye (i) ${ }^{2,3,6,7}$
}

Ambient sunlight-driven $\mathrm{CO}_{2}$ methanation cannot be realized due to the temperature being less than $80^{\circ} \mathrm{C}$ upon irradiation with dispersed solar energy. In this work, a selective light absorber was used to construct a photothermal system to generate a high temperature (up to $\left.288^{\circ} \mathrm{C}\right)$ under weak solar irradiation $\left(1 \mathrm{~kW} \mathrm{~m}^{-2}\right)$, and this temperature is three times higher than that in traditional photothermal catalysis systems. Moreover, ultrathin amorphous $\mathrm{Y}_{2} \mathrm{O}_{3}$ nanosheets with confined single nickel atoms $\left(\mathrm{SA} \mathrm{Ni} / \mathrm{Y}_{2} \mathrm{O}_{3}\right.$ ) were synthesized, and they exhibited superior $\mathrm{CO}_{2}$ methanation activity. As a result, $80 \% \mathrm{CO}_{2}$ conversion efficiency and a $\mathrm{CH}_{4}$ production rate of $7.5 \mathrm{~L} \mathrm{~m}^{-2} \mathrm{~h}^{-1}$ were achieved through $\mathrm{SA} \mathrm{Ni} / \mathrm{Y}_{2} \mathrm{O}_{3}$ under solar irradiation (from 0.52 to $0.7 \mathrm{~kW} \mathrm{~m}^{-2}$ ) when assisted by a selective light absorber, demonstrating that this system can serve as a platform for directly harnessing dispersed solar energy to convert $\mathrm{CO}_{2}$ to valuable chemicals.

\footnotetext{
${ }^{1}$ Hebei Key Lab of Optic-electronic Information and Materials, The College of Physics Science and Technology, Hebei University, Baoding 071002, P. R. China. ${ }^{2}$ Graduate School of Chemical Sciences and Engineering, Hokkaido University, Sapporo 060-0814, Japan. ${ }^{3}$ International Center for Materials Nanoarchitectonics (WPI-MANA), National Institute for Materials Science (NIMS), 1-1 Namiki, Tsukuba, Ibaraki 305-0044, Japan. ${ }^{4}$ Hebei Provincial Key Laboratory of Inorganic Nonmetallic Materials, College of Materials Science and Engineering, North China University of Science and Technology, Tangshan 063210 Hebei, P. R. China. ${ }^{5}$ Department of Chemistry, Zhejiang Normal University, Jinhua, Zhejiang 321004, China. ${ }^{6}$ TJU-NIMS International Collaboration Laboratory, School of Material Science and Engineering, Tianjin University, Tianjin 300072, P. R. China. ${ }^{7}$ Collaborative Innovation Center of Chemical Science and Engineering (Tianjin), Tianjin 300072, P. R. China. ${ }^{8}$ These authors contributed equally: Yaguang Li, Jianchao Hao, Hui Song. Correspondence and requests for materials should be addressed to Y.L. (email: yaguang_1987@126.com) or to S.W. (email: sfwang@hbu.edu.cn) or to Y.H. (email: yonghu@zjnu.edu.cn) or to J.Y. (email: Jinhua.YE@nims.go.jp)
} 
T he rapid consumption of fossil fuels has caused serious energy shortage problems, as well as greenhouse effects ${ }^{1-3}$. Methane $\left(\mathrm{CH}_{4}\right)$ is the main component of natural gas and is widely used as a source of clean energy with low carbon emissions ${ }^{4,5}$. Converting $\mathrm{CO}_{2}$ into synthetic natural gas through methanation has great significance for mitigating $\mathrm{CO}_{2}$ emissions $^{6,7}$ and realizing hydrogen storage 8,9 , as the excess electric power generated at night can be used for $\mathrm{H}_{2}$ production ${ }^{9-11}$. For $\mathrm{CO}_{2}$ methanation, a temperature of at least $200{ }^{\circ} \mathrm{C}$ is needed to activate the catalytic reaction ${ }^{12,13}$, thus requiring a secondary energy source ${ }^{14,15}$. Solar-driven $\mathrm{CO}_{2}$ methanation via a photothermal effect represents a promising strategy to produce $\mathrm{CH}_{4}$ without secondary energy input ${ }^{16-20}$. However, intense light irradiation (more than $10 \mathrm{~kW} \mathrm{~m}^{-2}$, equal to ten times the standard intensity of solar light) must be provided to heat the catalysts to $200^{\circ} \mathrm{C}$ to drive the $\mathrm{CO}_{2}$ methanation $^{5,21}$. Such intense irradiation requires complex instruments and increased energy consumption, limiting the potential of photothermal catalysis for industrial applications ${ }^{22}$. Thus, employing weak solar light $\left(1 \mathrm{~kW} \mathrm{~m}^{-2}\right)$ to achieve high temperatures for photothermal $\mathrm{CO}_{2}$ methanation as well as other photothermal catalytic reactions is quite challenging. To achieve this goal, metallic nanoparticles, carbon-based materials, etc. have been widely investigated as photothermal catalysts due to their ability to absorb the full solar spectrum ${ }^{23,24}$. Although they can absorb the full solar spectrum, their thermal radiation is high due to their blackbody nature ${ }^{25,26}$. The strong thermal radiation prevents heat storage by photothermal materials, leading to a $100^{\circ} \mathrm{C}$ limit of photothermal materials under $1 \operatorname{sun}^{27,28}$, which is not suitable for triggering photothermal $\mathrm{CO}_{2}$ methanation.

On the other hand, ruthenium $(\mathrm{Ru})$ catalysts have been verified as the best catalysts for photothermal $\mathrm{CO}_{2}$ methanation ${ }^{5,20}$. Since $\mathrm{Ru}$ is scarce, noble metal-free catalysts have to be developed to replace expensive $\mathrm{Ru}$ catalysts ${ }^{29}$. Unfortunately, the $\mathrm{CO}_{2}$ methanation reactions catalyzed by conventional base metals are sluggish $^{12,30}$. Therefore, the rational design of efficient methanation catalysts using base metals is highly desired. Recently, supported single-atom catalysts have demonstrated high activity in various reactions, such as hydrogenation, oxidation, and water-gas shift reactions ${ }^{31-34}$. Nickel-based catalysts are among the most active base-metal catalysts for thermal $\mathrm{CO}_{2}$ methanation $^{35}$. However, until now, few studies have been reported on isolated $\mathrm{Ni}$ atom catalysts for photothermal $\mathrm{CO}_{2}$ methanation.

In this work, benefiting from the addition of selective light absorbers that can both absorb the full solar spectrum and generate little thermal radiation ${ }^{36}$, we fabricate a photothermal conversion device that can heat catalysts to $288^{\circ} \mathrm{C}$ under 1 sun $\left(1 \mathrm{~kW} \mathrm{~m}^{-2}\right)$ and successfully propel weak sunlight-driven photothermal $\mathrm{CO}_{2}$ methanation. Furthermore, we prepared twodimensional amorphous $\mathrm{Y}_{2} \mathrm{O}_{3}$ nanosheets decorated with single $\mathrm{Ni}$ atoms $\left(\mathrm{SA} \mathrm{Ni} / \mathrm{Y}_{2} \mathrm{O}_{3}\right)$. Compared with other Ni-based catalysts, $\mathrm{SA} \mathrm{Ni} / \mathrm{Y}_{2} \mathrm{O}_{3}$ nanosheets show a lower initial reaction temperature and higher activity in $\mathrm{CO}_{2}$ methanation. Coupled with the selective light absorber-assisted photothermal system, the $\mathrm{SA} \mathrm{Ni} /$ $\mathrm{Y}_{2} \mathrm{O}_{3}$ nanosheets exhibit efficient and stable photothermal $\mathrm{CH}_{4}$ production under solar irradiation.

\section{Results}

Traditional and selective light absorber-assisted photothermal systems. $\mathrm{Y}_{2} \mathrm{O}_{3}$ nanosheets loaded with $4 \%$ wt Ni nanoparticles were prepared to demonstrate the solar absorption and heat storage of the state-of-the-art photothermal catalysts $\left(\mathrm{Ni} / \mathrm{Y}_{2} \mathrm{O}_{3}\right.$, Supplementary Fig. 1, synthesis details can be found in the Methods section). Figure 1a shows the black color of the $\mathrm{Ni} / \mathrm{Y}_{2} \mathrm{O}_{3}$ nanosheets. The ultraviolet-visible-infrared (UV-Vis-IR) absorption spectrum of the $\mathrm{Ni} / \mathrm{Y}_{2} \mathrm{O}_{3}$ nanosheets exhibits a photoresponse in the ultraviolet $(300 \mathrm{~nm})$ to visible and near-infrared (IR) spectral regions (up to $2 \mu \mathrm{m}$ ), confirming the $100 \%$ solar absorption capacity of the $\mathrm{Ni} / \mathrm{Y}_{2} \mathrm{O}_{3}$ nanosheets (Fig. 1b). Furthermore, the $\mathrm{Ni} / \mathrm{Y}_{2} \mathrm{O}_{3}$ nanosheets exhibit a high level of IR absorption in the $2-10 \mu \mathrm{m}$ range. Thermal radiation of materials is known as IR radiation ${ }^{37}$. Kirchhoff's law states that the IR emissivity is equal to the IR absorptivity of the material in thermodynamic equilibrium ${ }^{38}$. Therefore, the IR absorption of the $\mathrm{Ni} / \mathrm{Y}_{2} \mathrm{O}_{3}$ nanosheets leads to a strong IR radiation by the $\mathrm{Ni} / \mathrm{Y}_{2} \mathrm{O}_{3}$ nanosheets, resulting in intense heat dissipation ${ }^{39}$. Assuming that the $\mathrm{Ni} / \mathrm{Y}_{2} \mathrm{O}_{3}$ nanosheets are at $200^{\circ} \mathrm{C}$ (Fig. 1c), the IR radiative heat loss can be as high as $2.27 \mathrm{~kW} \mathrm{~m}^{-2}$, equivalent to 2.27 standard suns (based on the Stefan-Boltzmann law, see the details in the Methods section), far exceeding the one solar flux of $1 \mathrm{~kW} \mathrm{~m}{ }^{-2}$. This is the reason why the $\mathrm{Ni} / \mathrm{Y}_{2} \mathrm{O}_{3}$ nanosheets can only reach $78^{\circ} \mathrm{C}$ (Fig. 1h) and the $\mathrm{CO}_{2}$ methanation cannot be conducted with the $\mathrm{Ni} / \mathrm{Y}_{2} \mathrm{O}_{3}$ nanosheets under one sun (Fig. 1i). Therefore, high IR radiation is the bottleneck of photothermal materials for obtaining high temperatures under weak solar irradiation ${ }^{40}$. To overcome the energy radiation obstacle, we selected a selective light absorber $\left(\mathrm{AlN}_{\mathrm{x}} / \mathrm{Al}\right.$ foil) consisting of $\mathrm{Al}$ foil with a $2-\mu \mathrm{m}$ thick coating of $\operatorname{AlN}_{\mathrm{x}}$, as shown in Fig. $1 \mathrm{~d}$ and Supplementary Fig. 2. The UV-Vis-IR absorption spectrum of the selective light absorber exhibits an obvious absorption from $300 \mathrm{~nm}$ to $1300 \mathrm{~nm}$ (Fig. 1e), accounting for $\sim 100 \%$ of the solar spectrum, and little absorption in the IR region of $2-10 \mu \mathrm{m}$. According to the simulated calculations (Fig. 1f), the radiative heat loss from the selective light absorber is $0.21 \mathrm{~kW} \mathrm{~m}^{-2}$ at $200^{\circ} \mathrm{C}$ (see calculation details in the Methods section), equaling $10 \%$ of the thermal radiation of the $\mathrm{Ni} / \mathrm{Y}_{2} \mathrm{O}_{3}$ nanosheets at $200^{\circ} \mathrm{C}$ and $21 \%$ of the standard solar flux. We compared the temperatures of several typical photothermal materials under 1 sun, and $103^{\circ} \mathrm{C}$ was the highest temperature reached by photothermal materials with vacuum thermal insulation (Supplementary Table 1 ), which is $34 \%$ of the temperature achieved by a selective light absorber $\left(300^{\circ} \mathrm{C}\right)$. We designed a photothermal system using a selective light absorber. As shown in Fig. $1 \mathrm{~g}$ and Supplementary Fig. 3, the outside of a quartz tube is coated with the selective light absorber to achieve the high temperature. The $\mathrm{Ni} /$ $\mathrm{Y}_{2} \mathrm{O}_{3}$ nanosheets were coated onto the inside of a flow-type quartz tube. Figure $1 \mathrm{~h}$ indicates that the temperature of the $\mathrm{Ni} /$ $\mathrm{Y}_{2} \mathrm{O}_{3}$ nanosheets in the selective light absorber-assisted photothermal system can be as high as $288^{\circ} \mathrm{C}$ under $1.0 \mathrm{~kW} \mathrm{~m}^{-2}$ solar irradiation, 3.7 times higher than that of $\mathrm{Ni} / \mathrm{Y}_{2} \mathrm{O}_{3}$ nanosheets directly irradiated by the same light. The photothermal $\mathrm{CO}_{2}$ methanation efficiency reached $80 \%$ under $1.0 \mathrm{~kW} \mathrm{~m}^{-2}$ solar illumination (Fig. 1i). For comparison, the traditional photothermal system reported by Ye et al. showed that photothermal $\mathrm{CO}_{2}$ methanation could not be achieved by $\mathrm{Ni} / \mathrm{Al}_{2} \mathrm{O}_{3}$, due to the one solar-driven temperature of $81^{\circ} \mathrm{C}^{20}$, revealing the significant advantage of a selective light absorber in weak sunlight-driven photothermal catalysis.

Preparation and characterization of $\mathrm{SA} \mathrm{Ni} / \mathrm{Y}_{2} \mathrm{O}_{3}$ nanosheets. In addition to increasing the photon-induced temperature, we also tried to enhance the activity of Ni-based catalysts. The size of the $\mathrm{Ni}$ species can be as small as a single atom on the $\mathrm{Y}_{2} \mathrm{O}_{3}$ nanosheets $\left(\mathrm{SA} \mathrm{Ni} / \mathrm{Y}_{2} \mathrm{O}_{3}\right.$ ) by a bimetal ion-adsorption method ${ }^{41}$. As illustrated in Fig. 2a, briefly, $\mathrm{Ni}\left(\mathrm{NO}_{3}\right)_{2} \cdot 6 \mathrm{H}_{2} \mathrm{O}$ and $\mathrm{Y}$ $\left(\mathrm{NO}_{3}\right)_{3} \cdot 6 \mathrm{H}_{2} \mathrm{O}$ were dissolved in water to obtain a solution. Then, graphene oxide (GO) was added into the solution to adsorb the $\mathrm{Ni}^{2+}$ and $\mathrm{Y}^{3+}$ metal ions. The $\mathrm{SA} \mathrm{Ni} / \mathrm{Y}_{2} \mathrm{O}_{3}$ nanosheets were obtained after the washing, freeze drying, and annealing (see the Methods for synthesis details). As determined by inductively 
a
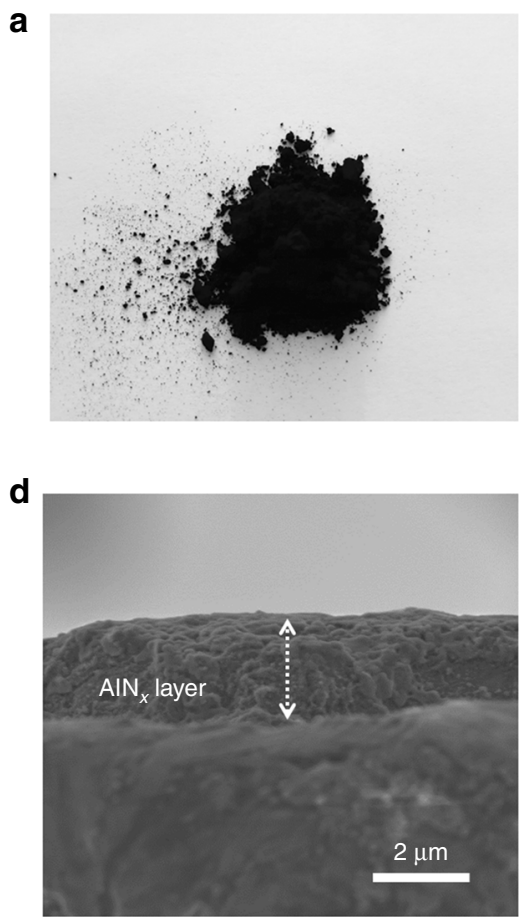

g

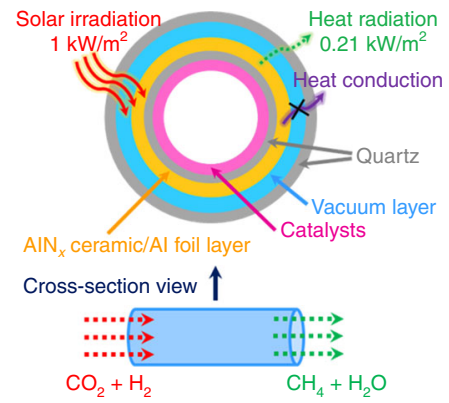

b

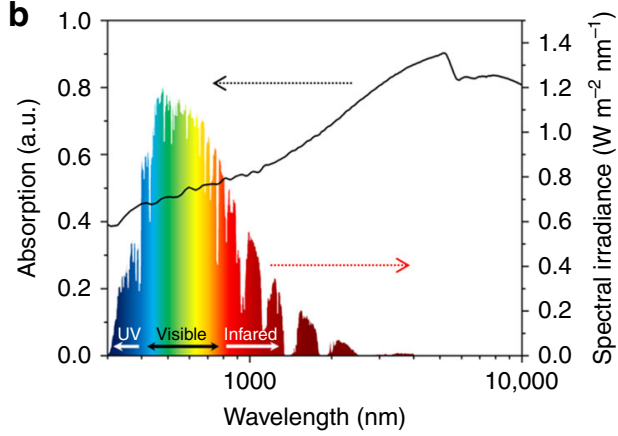

C

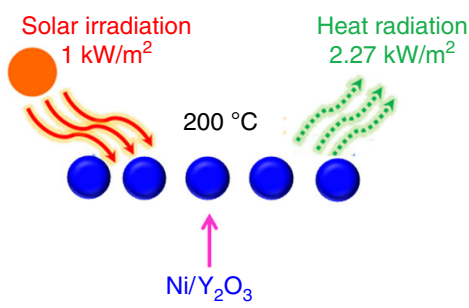

f

Solar irradiation Heat radiation $1 \mathrm{~kW} / \mathrm{m}^{2} \quad 0.21 \mathrm{~kW} / \mathrm{m}^{2}$

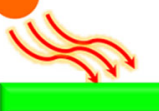

$200{ }^{\circ} \mathrm{C}$

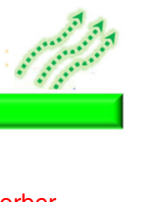

Selective light absorber
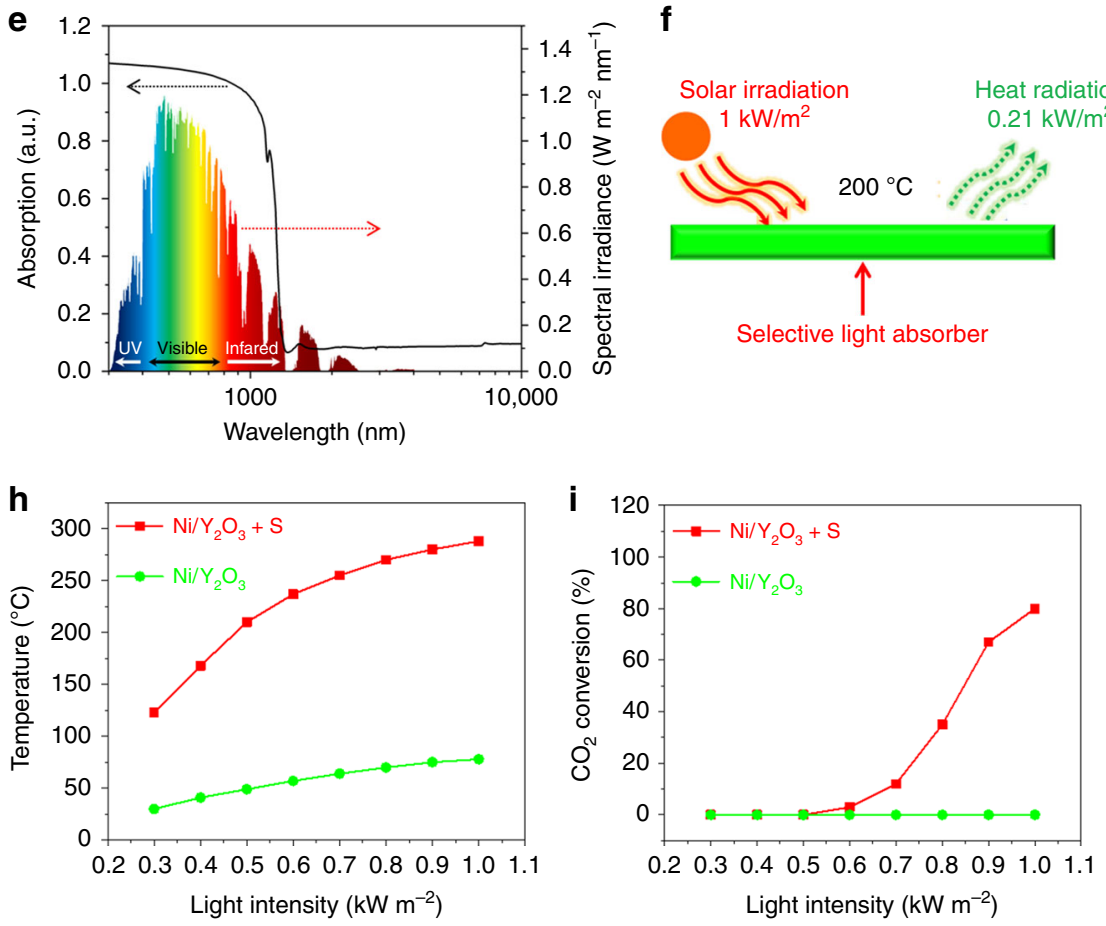

Fig. 1 Traditional and selective light absorber-assisted photothermal systems. a Photograph of the $\mathrm{Ni} / \mathrm{Y}_{2} \mathrm{O}_{3}$ nanosheets powder. b Normalized UV-Vis-IR absorption spectrum of the $\mathrm{Ni} / \mathrm{Y}_{2} \mathrm{O}_{3}$ nanosheets. c Solar energy absorption and thermal radiation diagram for the $\mathrm{Ni} / \mathrm{Y}_{2} \mathrm{O}_{3}$ nanosheets at $200{ }^{\circ} \mathrm{C}$. The ambient solar flux of $1 \mathrm{~kW} \mathrm{~m}^{-2}$ is not enough to sustain the thermal radiation; thus, an equilibrium temperature of $200^{\circ} \mathrm{C}$ cannot be obtained. $\mathbf{d}$ Crosssectional SEM image and $\mathbf{e}$ normalized UV-Vis-IR absorption spectrum of the selective light absorber $\left(\mathrm{AIN}_{\mathrm{x}} / \mathrm{Al}\right.$ foil). f Solar energy absorption and thermal radiation diagram of the selective light absorber at $200^{\circ} \mathrm{C}$. The thermal radiation was far below the absorbed energy from ambient solar flux. $\mathbf{g}$ Schematic of the new photothermal system used for photothermal $\mathrm{CO}_{2}$ methanation with the selective absorber and the catalysts. $\mathbf{h}$, $\mathbf{i}$ The light-driven temperature and $\mathrm{CO}_{2}$ conversion rates of the $\mathrm{Ni} / \mathrm{Y}_{2} \mathrm{O}_{3}$ nanosheets with $\left(\mathrm{Ni} / \mathrm{Y}_{2} \mathrm{O}_{3}+\mathrm{S}\right.$ red) and without $\left(\mathrm{Ni} / \mathrm{Y}_{2} \mathrm{O}_{3}\right.$ green $)$ the selective light absorber-assisted photothermal system, respectively, under different intensities of sunlight irradiation. The scale bar in $\mathbf{d}$ is $2000 \mathrm{~nm}$

coupled plasma-atomic emission spectroscopy (ICP-AES), the weight percentage of $\mathrm{Ni}$ in the $\mathrm{SA} \mathrm{Ni} / \mathrm{Y}_{2} \mathrm{O}_{3}$ nanosheets was $3.9 \mathrm{wt}$ $\%$ (in this paper, the amount of $\mathrm{Ni}$ in all the $\mathrm{SA} \mathrm{Ni} / \mathrm{Y}_{2} \mathrm{O}_{3}$ nanosheets is $3.9 \mathrm{wt} \%$, unless otherwise stated). Figure $2 \mathrm{~b}$ shows the X-ray diffraction (XRD) pattern of the $\mathrm{SA} \mathrm{Ni} / \mathrm{Y}_{2} \mathrm{O}_{3}$ nanosheets, indicating the amorphous nature of the product. The Brunauer-Emmett-Teller (BET) specific area of the SA Ni/ $\mathrm{Y}_{2} \mathrm{O}_{3}$ nanosheets (Fig. 2c) was as high as $425 \mathrm{~m}^{2} \mathrm{~g}^{-1}$, ensuring a large number of active sites for catalytic reactions. The lowmagnification scanning electron microscopy (SEM) image (Fig. 2d) revealed that the $\mathrm{SA} \mathrm{Ni} / \mathrm{Y}_{2} \mathrm{O}_{3}$ nanosheets exhibit a silklike morphology with a typical length of a few micrometers. The transmission electron microscopy (TEM) image in Fig. 2e further confirms the ultrathin structure of the 2D nanosheets. The average thickness of the $\mathrm{SA} \mathrm{Ni} / \mathrm{Y}_{2} \mathrm{O}_{3}$ nanosheets is $\sim 1.5 \mathrm{~nm}$ (Supplementary Fig. 4). The high-resolution TEM image (Fig. 2f) and the corresponding selected area electron diffraction (SAED) pattern (inset in Fig. 2f) reveal no lattice fringes or indistinct diffraction rings in the $\mathrm{SA} \mathrm{Ni} / \mathrm{Y}_{2} \mathrm{O}_{3}$ nanosheets, confirming the absence of $\mathrm{Ni}$ nanoparticles. Moreover, the elemental mapping of the $\mathrm{SA} \mathrm{Ni} / \mathrm{Y}_{2} \mathrm{O}_{3}$ nanosheets revealed that $\mathrm{Ni}, \mathrm{Y}$, and $\mathrm{O}$ are homogeneously distributed throughout the $\mathrm{SA} \mathrm{Ni} / \mathrm{Y}_{2} \mathrm{O}_{3}$ nanosheets (Fig. 2g).

To confirm the presence state of $\mathrm{Ni}$ on the $\mathrm{SA} \mathrm{Ni} / \mathrm{Y}_{2} \mathrm{O}_{3}$ sheets, aberration-corrected TEM measurements were performed. Figure $3 \mathrm{a}$ indicates that no precipitates larger than $1 \mathrm{~nm}$ can be found on the nanosheets, and only several small dark dots were visible on the nanosheets. These dots were $1-3 \AA$ in diameter, similar to the size of single atoms or small clusters composed of several atoms. To further verify the structure of the Ni species on the $\mathrm{SA} \mathrm{Ni} / \mathrm{Y}_{2} \mathrm{O}_{3}$ nanosheets, extended $\mathrm{X}$-ray absorption fine structure (EXAFS) analysis was conducted. As shown in Fig. 3b, 
a
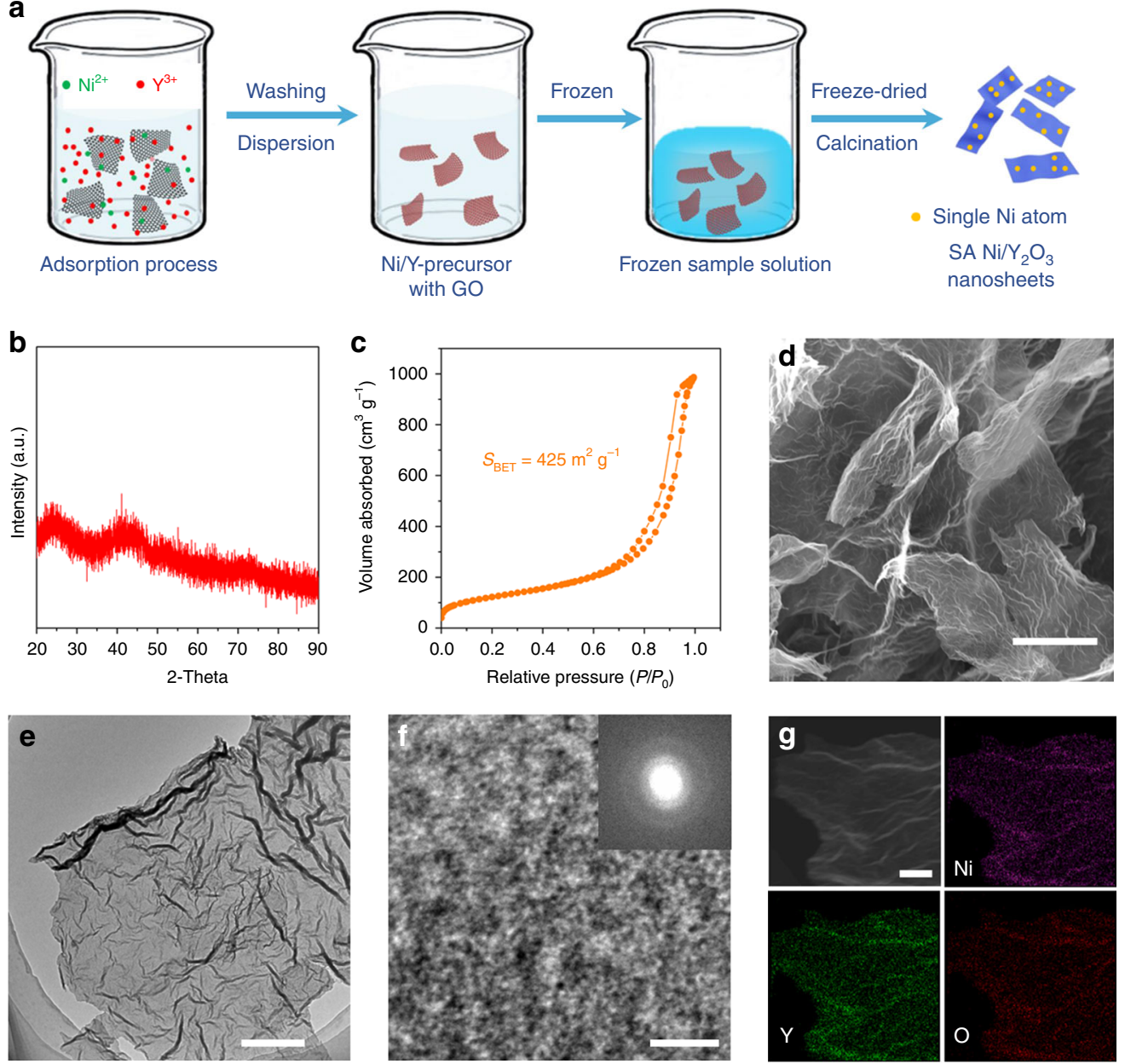

Fig. 2 Preparation and characterization of the $\mathrm{SA} \mathrm{Ni} / \mathrm{Y}_{2} \mathrm{O}_{3}$ nanosheets. a Schematic of the preparation process for $\mathrm{Y}_{2} \mathrm{O}_{3}$ nanosheets decorated with single $\mathrm{Ni}$ atoms $\left(\mathrm{SA} \mathrm{Ni} / \mathrm{Y}_{2} \mathrm{O}_{3}\right.$ ). b XRD pattern, $\mathbf{c ~ N} \mathrm{N}_{2}$ adsorption-desorption isotherm, $\mathbf{d}$ SEM image, e TEM image, $\mathbf{f}$ HRTEM image, $\mathbf{g}$ STEM image, and EDS mapping images of $\mathrm{Ni}, \mathrm{Y}$, and $\mathrm{O}$ of the $\mathrm{SA} \mathrm{Ni} / \mathrm{Y}_{2} \mathrm{O}_{3}$ nanosheets. The inset in $\mathbf{f}$ is the corresponding electron diffraction pattern. The scale bars in $\mathbf{d}, \mathbf{e}, \mathbf{f}$, and $\mathbf{g}$ are 1000, 200, 2, and $20 \mathrm{~nm}$, respectively

the EXAFS curves show that the near-edge absorption energy of the $\mathrm{SA} \mathrm{Ni} / \mathrm{Y}_{2} \mathrm{O}_{3}$ nanosheets is higher than that of $\mathrm{Ni}$ foil and lower than that of $\mathrm{NiO}$, showing that the oxidation state of the $\mathrm{Ni}$ species in $\mathrm{Ni} / \mathrm{Y}_{2} \mathrm{O}_{3}$ nanosheets (Supplementary Fig. 5). The Fourier transform (FT)-EXAFS curve (Fig. 3c) for the SA Ni/ $\mathrm{Y}_{2} \mathrm{O}_{3}$ nanosheets shows only a main peak at $\sim 1.7 \AA$, which could be attributed to $\mathrm{Ni}-\mathrm{O}$ scattering. The small signals from $\mathrm{Ni}-\mathrm{Ni}$ at approximately $2.1 \AA$ and $\mathrm{Ni}-\mathrm{O}-\mathrm{Ni}$ at $\sim 2.5 \AA^{42,43}$ confirm that the $\mathrm{Ni}$ is mainly distributed as single atoms on the $\mathrm{SA} \mathrm{Ni} / \mathrm{Y}_{2} \mathrm{O}_{3}$ nanosheets. The structure of amorphous $\mathrm{Y}_{2} \mathrm{O}_{3}$ decorated with single $\mathrm{Ni}$ atoms is illustrated in the inset of Fig. $3 \mathrm{~d}$. The simulated Ni-coordinated FT-EXAFS spectrum of this model (Fig. 3d) fits well with the measured spectrum of the $\mathrm{SA} \mathrm{Ni} / \mathrm{Y}_{2} \mathrm{O}_{3}$ nanosheets, further confirming single $\mathrm{Ni}$ atoms are the dominant $\mathrm{Ni}$ species on the $\mathrm{SA} \mathrm{Ni} / \mathrm{Y}_{2} \mathrm{O}_{3}$ nanosheets.

$\mathrm{CO}_{2}$ methanation performance of the $\mathrm{SA} \mathrm{Ni} / \mathrm{Y}_{2} \mathrm{O}_{3}$ nanosheets. The catalytic performance of the as-obtained $\mathrm{SA} \mathrm{Ni} / \mathrm{Y}_{2} \mathrm{O}_{3}$ nanosheets was evaluated in $\mathrm{CO}_{2}$ hydrogenation. First, an experiment was performed using the $\mathrm{Y}_{2} \mathrm{O}_{3}$ nanosheets as the catalyst. The $\mathrm{CO}_{2}$ conversion by the $\mathrm{Y}_{2} \mathrm{O}_{3}$ nanosheets was negligible, as presented in Supplementary Fig. 6. With the SA Ni/ $\mathrm{Y}_{2} \mathrm{O}_{3}$ nanosheets, $\mathrm{CO}_{2}$ reduction started at $\sim 180^{\circ} \mathrm{C}$, and a conversion rate of $\sim 87 \%$ was achieved at $240{ }^{\circ} \mathrm{C}$ (Fig. 4 a), while the
$\mathrm{CO}_{2}$ conversion with $\mathrm{Ni} / \mathrm{Y}_{2} \mathrm{O}_{3}$ nanosheets was $\sim 11 \%$ at the same temperature, corresponding to $13 \%$ of that achieved with the SA $\mathrm{Ni} / \mathrm{Y}_{2} \mathrm{O}_{3}$ nanosheets. Since the amount of $\mathrm{Ni}$ and the surface areas of the SA Ni/ $\mathrm{Y}_{2} \mathrm{O}_{3}$ nanosheets and $\mathrm{Ni} / \mathrm{Y}_{2} \mathrm{O}_{3}$ nanosheets are similar (Supplementary Table 2), the difference in the $\mathrm{CO}_{2}$ conversion reveals that the $\mathrm{Ni}$ single atoms lead to the high $\mathrm{CO}_{2}$ methanation activity of the $\mathrm{SA} \mathrm{Ni} / \mathrm{Y}_{2} \mathrm{O}_{3}$ nanosheets in comparison with the $\mathrm{Ni} / \mathrm{Y}_{2} \mathrm{O}_{3}$ nanosheets. We have compared some noble metal-free catalysts for thermal $\mathrm{CO}_{2}$ methanation in Supplementary Table 3. The thermal $\mathrm{CO}_{2}$ methanation activity of the SA Ni/ $\mathrm{Y}_{2} \mathrm{O}_{3}$ nanosheets is higher than those reported for other Ni-based catalysts ${ }^{13,44-46}$. Figure $4 \mathrm{~b}$ shows that nearly $100 \%$ selectivity for $\mathrm{CH}_{4}$ formation is achieved in the thermal $\mathrm{CO}_{2}$ hydrogenation with the $\mathrm{SA} \mathrm{Ni} / \mathrm{Y}_{2} \mathrm{O}_{3}$ nanosheets at different reaction temperatures, revealing high selectivity for $\mathrm{CH}_{4}$. During the 90-h heating/cooling tests, the $\mathrm{CO}_{2}$ conversion rate of the SA $\mathrm{Ni} / \mathrm{Y}_{2} \mathrm{O}_{3}$ nanosheets at $240{ }^{\circ} \mathrm{C}$ was maintained at $\sim 87 \%$ (Fig. $4 \mathrm{c}$ ), indicating excellent catalytic stability. Supplementary Fig. 7 shows that the morphology of the $\mathrm{SA} \mathrm{Ni} / \mathrm{Y}_{2} \mathrm{O}_{3}$ nanosheets was retained after $90 \mathrm{~h}$ of testing, and several small dark dots remained on the $\mathrm{SA} \mathrm{Ni} / \mathrm{Y}_{2} \mathrm{O}_{3}$ nanosheets after the stability test, but cleat Ni precipitation was not observed (Fig. 4d), confirming the robustness of the $\mathrm{SA} \mathrm{Ni} / \mathrm{Y}_{2} \mathrm{O}_{3}$ nanosheets in thermal $\mathrm{CO}_{2}$ methanation. 

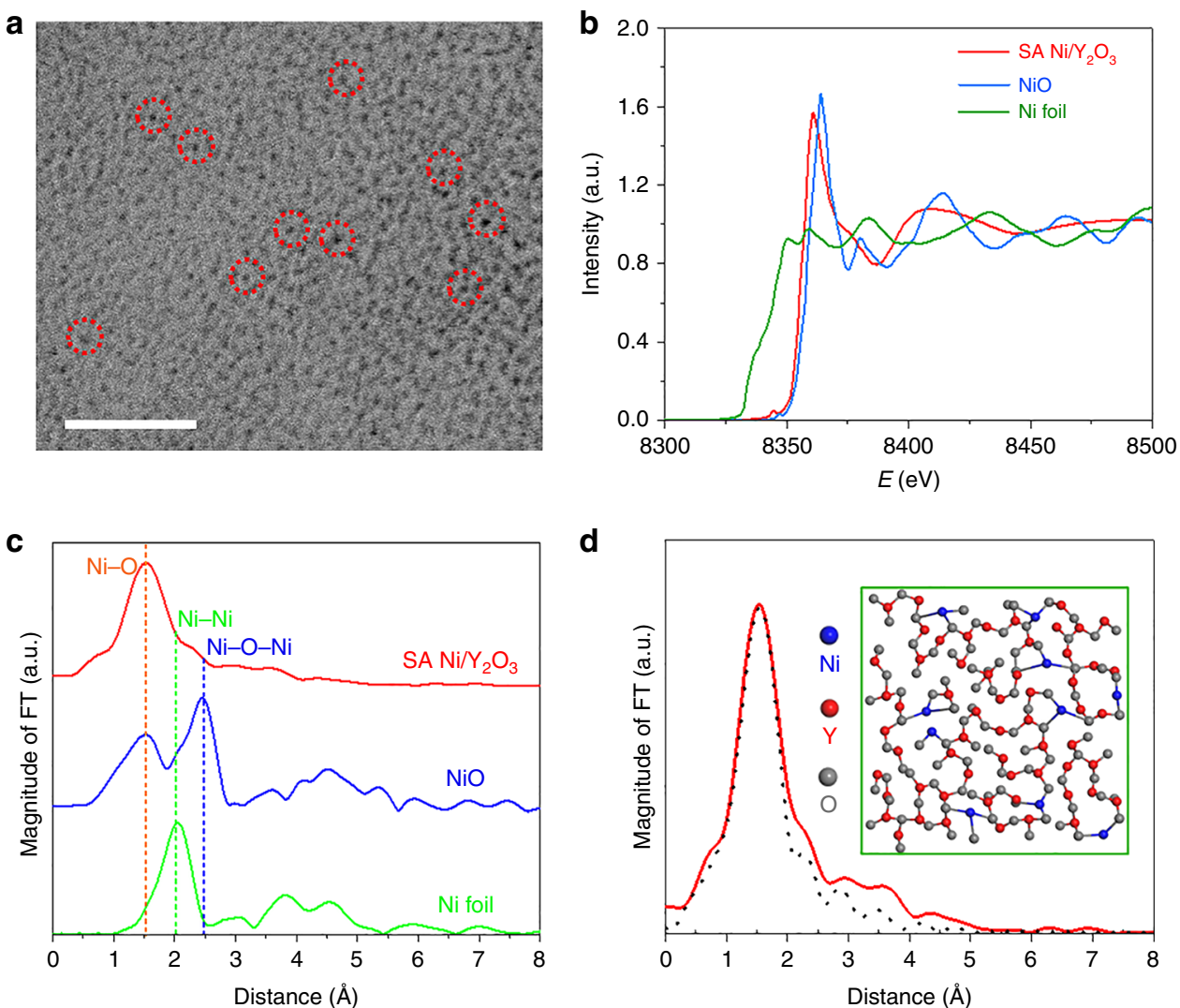

Fig. 3 Characterization of the $\mathrm{Ni}$ in the $\mathrm{SA} \mathrm{Ni} / \mathrm{Y}_{2} \mathrm{O}_{3}$ nanosheets. a Aberration-corrected TEM image of the $\mathrm{SA} \mathrm{Ni} / \mathrm{Y}_{2} \mathrm{O}_{3}$ nanosheets. $\mathbf{b}$ EXAFS spectra of the $\mathrm{Ni}$ K-edge of the SA Ni/ $\mathrm{Y}_{2} \mathrm{O}_{3}$ nanosheets, $\mathrm{NiO}$ and $\mathrm{Ni}$ foil. c Fourier transform (FT) of the Ni K-edge of the SA Ni/ $\mathrm{Y}_{2} \mathrm{O}_{3}$ nanosheets, $\mathrm{NiO}$ and $\mathrm{Ni}$ foil. d Schematic model of the SA Ni/ $\mathrm{Y}_{2} \mathrm{O}_{3}$ nanosheets and the corresponding FT-EXAFS fitting curves for the SA Ni/ $\mathrm{Y}_{2} \mathrm{O}_{3}$ nanosheets. The scale bar in a is $2 \mathrm{~nm}$

The photothermal $\mathrm{CO}_{2}$ methanation with the $\mathrm{SA} \mathrm{Ni} / \mathrm{Y}_{2} \mathrm{O}_{3}$ nanosheets assisted by a selective light absorber is depicted in Fig. 5. Figure 5a shows the spatial temperature mapping of the photothermal system under simulated 1 sun $\left(1.0 \mathrm{~kW} \mathrm{~m}^{-2}\right)$ in air. The highest temperature recorded by the IR camera was $\sim 255^{\circ} \mathrm{C}$. When the gas inlet and outlet are encapsulated by thermal insulating covers, the temperature of the $\mathrm{SA} \mathrm{Ni} / \mathrm{Y}_{2} \mathrm{O}_{3}$ nanosheet layer probed by the thermometer increased to $285^{\circ} \mathrm{C}$ under $1.0 \mathrm{~kW} \mathrm{~m}^{-2}$ solar irradiation and exceeded $200^{\circ} \mathrm{C}$ under 0.5 $\mathrm{kW} \mathrm{m}{ }^{-2}$ irradiation. The photothermal $\mathrm{CO}_{2}$ methanation started at only $0.4 \mathrm{~kW} \mathrm{~m}^{-2}$ irradiation, and the conversion rate was $90 \%$ under one sun (Fig. 5b). The selective sunlight absorber does not affect the high $\mathrm{CH}_{4}$ selectivity of the $\mathrm{SA} \mathrm{Ni} / \mathrm{Y}_{2} \mathrm{O}_{3}$ nanosheets, and nearly $100 \% \quad \mathrm{CH}_{4}$ selectivity was observed under different intensities of light irradiation (Supplementary Fig. 8). Moreover, the $\mathrm{SA} \mathrm{Ni} / \mathrm{Y}_{2} \mathrm{O}_{3}$ nanosheets also show excellent stability in the photothermal system under 1 sun (Supplementary Fig. 9). We directly performed $\mathrm{CO}_{2}$ methanation experiments under outdoor sunlight. The experiment was carried out from 08:00 to 18:00 under natural sunlight with a maximum intensity of $\sim 0.7$ $\mathrm{kW} \mathrm{m}^{-2}$ (Fig. 5c). As displayed in Fig. 5d, the $\mathrm{CO}_{2}$ methanation started at 9:00 am and increased gradually as time passed. The conversion remained at $\sim 90 \%$ from $11: 00$ to $16: 00$ and decreased after 16:00. We calculated the photothermal $\mathrm{CO}_{2}$ methanation rate from 10:00 to 16:00. The $\mathrm{CH}_{4}$ production rate was $7.5 \mathrm{~L} \mathrm{~m}^{-2} \mathrm{~h}^{-1}$ under ambient sunlight (the calculation details are provided in the Methods section), indicating that industrialgrade $\mathrm{CO}_{2}$ methanation has been achieved under ambient sunlight without additional energy input.

\section{Discussion}

In this study, we have synthesized amorphous $\mathrm{Y}_{2} \mathrm{O}_{3}$ nanosheets decorated with single $\mathrm{Ni}$ atoms at a $3.9 \% \mathrm{Ni}$ mass ratio ( $\mathrm{SA} \mathrm{Ni} / \mathrm{Y}_{2} \mathrm{O}_{3}$ nanosheets), having a specific surface area of 425 $\mathrm{m}^{2} \mathrm{~g}^{-1}$. The $\mathrm{SA} \mathrm{Ni} / \mathrm{Y}_{2} \mathrm{O}_{3}$ nanosheets exhibit a lower initiating temperature of $180{ }^{\circ} \mathrm{C}$ for $\mathrm{CO}_{2}$ methanation, $\sim 100 \%$ methanation selectivity and $\sim 87 \% \mathrm{CO}_{2}$ conversion at $240{ }^{\circ} \mathrm{C}$. In particular, a selective light absorber was employed to construct the photothermal system, which can reach $288^{\circ} \mathrm{C}$ under one sun. Therefore, the solar-driven photothermal $\mathrm{CO}_{2}$ methanation using the $\mathrm{SA} \mathrm{Ni} / \mathrm{Y}_{2} \mathrm{O}_{3}$ nanosheets exhibits $90 \%$ conversion efficiency and $100 \%$ methane selectivity with the assistance of a selective light absorber. Moreover, under ambient daytime sunlight (from 0.52 to $0.7 \mathrm{~kW} \mathrm{~m}^{-2}$ ), a photothermal $\mathrm{CO}_{2}$ methanation conversion efficiency of more than $80 \%$ and a methane production rate of $7.5 \mathrm{~L} \mathrm{~mol} \mathrm{~m}^{-2} \mathrm{~h}^{-1}$ are achieved using this system. The strategy of coupling an efficient $2 \mathrm{D}$ base-metal catalyst with a selective light absorber demonstrates great potential for solar-to-chemical energy conversion.

\section{Methods}

Chemicals. Commercial nickel nitrate hexahydrate $\left(\mathrm{Ni}\left(\mathrm{NO}_{3}\right)_{2} \cdot 6 \mathrm{H}_{2} \mathrm{O}\right)$ and yttrium

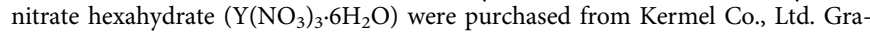
phene oxide (GO) was purchased from Hangzhou Gaoxi Technology Co., Ltd. Liquid nitrogen was purchased from Xicheng Special Gas Co., Ltd. The selective light absorber $\left(\mathrm{AlN}_{\mathrm{x}} / \mathrm{Al}\right.$ foil) was provided by Hangzhou Ruijia Precision Science Instrument Co., Ltd. All chemicals were directly used as received without further treatment. 

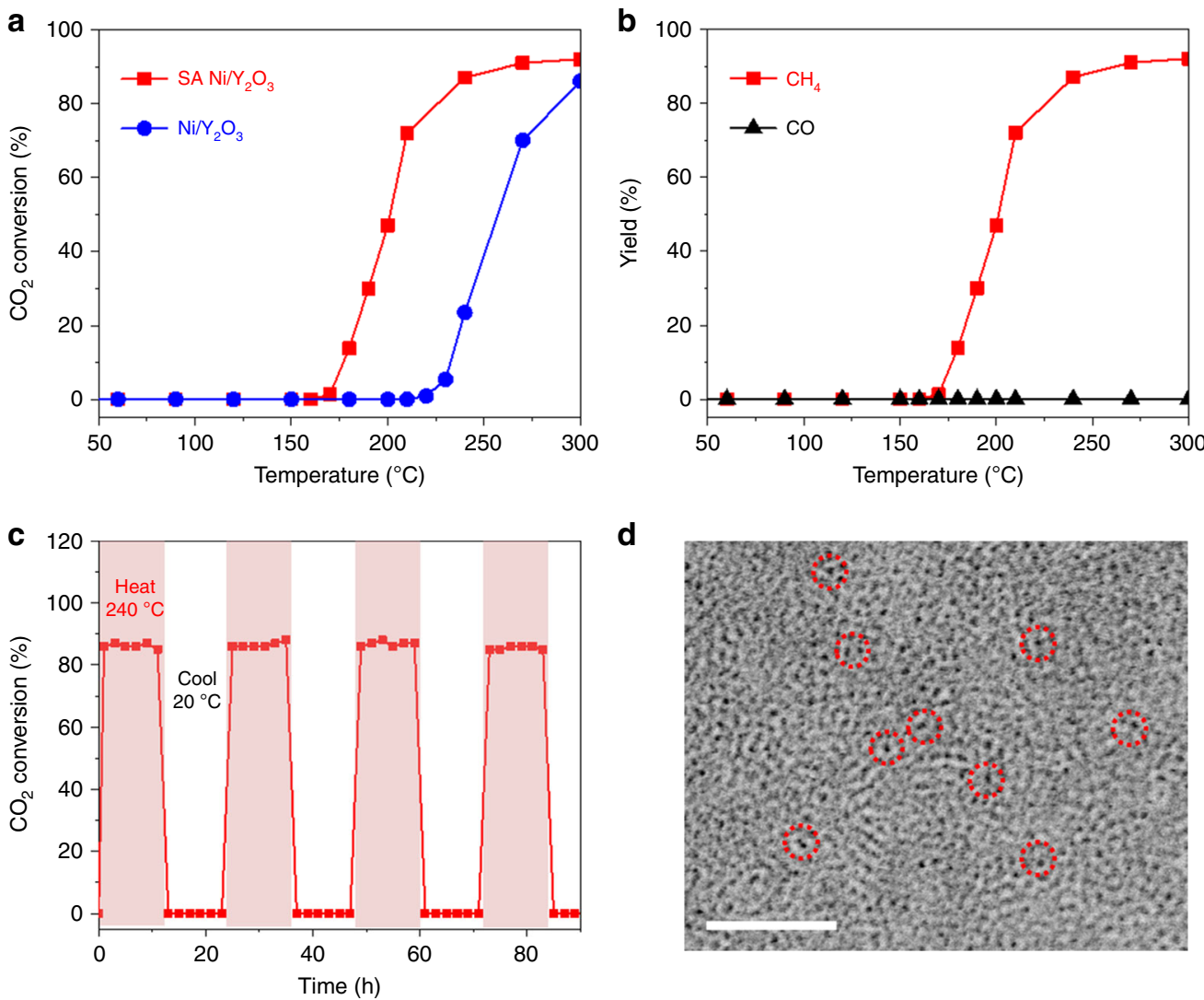

Fig. 4 Thermocatalytic $\mathrm{CO}_{2}$ hydrogenation experiments. a Thermal $\mathrm{CO}_{2}$ conversion using the $\mathrm{SANi} / \mathrm{Y}_{2} \mathrm{O}_{3}$ nanosheets $\left(\mathrm{SA} \mathrm{Ni} / \mathrm{Y}_{2} \mathrm{O}_{3}\right.$ ) and $\mathrm{Ni}$ nanoparticles/ $\mathrm{Y}_{2} \mathrm{O}_{3}$ nanosheets $\left(\mathrm{Ni} / \mathrm{Y}_{2} \mathrm{O}_{3}\right)$ as a function of temperature. $\mathbf{b} \mathrm{CH}_{4}$ and $\mathrm{CO}$ yields from the $\mathrm{CO}_{2}$ hydrogenation over the $\mathrm{SA} \mathrm{Ni} / \mathrm{Y}_{2} \mathrm{O}_{3}$ nanosheets as a function of temperature. $\mathbf{c} \mathrm{CO}_{2}$ hydrogenation versus reaction time over the $\mathrm{SA} \mathrm{Ni} / \mathrm{Y}_{2} \mathrm{O}_{3}$ nanosheets at $240{ }^{\circ} \mathrm{C}$. $\mathbf{d}$ Aberration-corrected TEM image of the $\mathrm{SA} \mathrm{Ni} / \mathrm{Y}_{2} \mathrm{O}_{3}$ nanosheets after the stability test shown in Fig. 4c. Reaction conditions: $100 \mathrm{ml} \mathrm{min}{ }^{-1}$ of reaction gas $\left(2.5 \% \mathrm{CO}_{2}+10 \% \mathrm{H}_{2}+87.5 \% \mathrm{~N}_{2}\right), 100$ $\mathrm{mg}$ of catalyst. The scale bar in $\mathbf{d}$ is $2 \mathrm{~nm}$

Synthesis of $\mathbf{N i} / \mathrm{Y}_{2} \mathrm{O}_{3}$ nanosheets. To synthesize the $\mathrm{Ni} / \mathrm{Y}_{2} \mathrm{O}_{3}$ nanosheets, we first synthesized $\mathrm{Y}_{2} \mathrm{O}_{3}$ nanosheets. Three grams of $\mathrm{Y}\left(\mathrm{NO}_{3}\right)_{3}$ was dispersed in 100 $\mathrm{ml}$ of water, and then $100 \mathrm{ml}$ of $\mathrm{GO}$ dispersed in water $(2 \mathrm{mg} / \mathrm{ml})$ was added into the above solution to adsorb the $\mathrm{Y}^{3+}$ metal ions on the surface of the GO sheets. After washing and centrifugation with water, the product was dispersed in pure deionized water by ultrasonic treatment. Subsequently, the solution was frozen in liquid nitrogen and then freeze-dried for 3 days. The product was calcined in air at $400{ }^{\circ} \mathrm{C}$ for $24 \mathrm{~h}$ to remove the GO nanosheets and mineralize the metal ions as $\mathrm{Y}_{2} \mathrm{O}_{3}$ nanosheets. Then, a certain amount of $\mathrm{Ni}\left(\mathrm{NO}_{3}\right)_{2}$ was dissolved in water. After that, $200 \mathrm{mg}$ of the $\mathrm{Y}_{2} \mathrm{O}_{3}$ nanosheets was dispersed into the above solution. After stirring for $2 \mathrm{~h}$, the samples were dried at $80^{\circ} \mathrm{C}$ and calcined in air at $400{ }^{\circ} \mathrm{C}$ for $4 \mathrm{~h}$ to prepare the NiO-loaded $\mathrm{Y}_{2} \mathrm{O}_{3}$ nanosheets $\left(\mathrm{NiO} / \mathrm{Y}_{2} \mathrm{O}_{3}\right.$ nanosheets). Then, the $\mathrm{NiO} / \mathrm{Y}_{2} \mathrm{O}_{3}$ nanosheets were reduced under $10 \% \mathrm{H}_{2} / \mathrm{Ar}$ at $400{ }^{\circ} \mathrm{C}$ for $2.5 \mathrm{~h}$ to prepare the $\mathrm{Ni} / \mathrm{Y}_{2} \mathrm{O}_{3}$ nanosheets. The loadings of Ni were $\sim 4.0 \mathrm{wt} \%$, based on ICPAES.

Synthesis $\mathbf{S A ~ N i} / \mathbf{Y}_{\mathbf{2}} \mathbf{O}_{\mathbf{3}}$. To synthesize $3.9 \mathrm{wt} \% \mathrm{SA} \mathrm{Ni} / \mathrm{Y}_{2} \mathrm{O}_{3}$ nanosheets, we selected single-layered exfoliated $\mathrm{GO}$ sheets as the substrate. First, $0.8 \mathrm{~g}$ of Ni $\left(\mathrm{NO}_{3}\right)_{2}$ and $3 \mathrm{~g}$ of $\mathrm{Y}\left(\mathrm{NO}_{3}\right)_{3}$ were dispersed in $100 \mathrm{ml}$ of water, and then $100 \mathrm{ml}$ of GO dispersed in water $(2 \mathrm{mg} / \mathrm{ml})$ was added into the above solution to adsorb the $\mathrm{Ni}^{2+}$ and $\mathrm{Y}^{3+}$ metal ions onto the surface of the GO sheets. After washing with water and centrifugation, the product was dispersed in pure deionized water by ultrasonic treatment. Subsequently, the solution was frozen in liquid nitrogen and then freeze-dried for 3 days. The product was calcined in air at $400{ }^{\circ} \mathrm{C}$ for $24 \mathrm{~h}$ to remove the GO nanosheets and mineralize the metal ions as metal oxide nanosheets. Then, the 2D metal oxide nanosheets were reduced with $10 \% \mathrm{H}_{2} / \mathrm{Ar}$ at $400{ }^{\circ} \mathrm{C}$ for $2.5 \mathrm{~h}$ to obtain the SA Ni/ $\mathrm{Y}_{2} \mathrm{O}_{3}$ nanosheets. The loadings of $\mathrm{Ni}$ were $\sim 3.9 \mathrm{wt} \%$ based on ICP-AES.

Catalyst characterization. Scanning electron microscopy (FEI Nova Nano SEM450) was used to identify the holistic and porous morphologies of the samples. The prepared samples were studied by powder X-ray diffraction, which was performed on a Bede D1 system operated at $20 \mathrm{kV}$ and $30 \mathrm{~mA}$ with $\mathrm{Cu} \mathrm{Ka}$ radiation $(\lambda=1.5406 \AA$ ). TEM (JEOL 2100 plus + ARM 200 F) was used to identify the morphology and crystal structure of the nanostructures as well as EDS mapping. The XPS spectra were recorded on a Thermo ESCALAB-250 spectrometer using a monochromatic $\mathrm{Al} \mathrm{Ka}$ radiation source $(1486.6 \mathrm{eV})$. The binding energies determined by XPS were corrected by referencing the adventitious carbon peak $(284.6$ $\mathrm{eV})$ for each sample. The BET surface areas were obtained using a Micromeritics Tristar 3020 system.

EXAFS test and analysis. The ex situ Ni K-edge extended X-ray absorption fine structure (EXAFS) data were collected on the beamline at Shanghai Synchrotron Radiation Facility (SSRF). All samples were prepared by placing a small amount of homogenized (via agate mortar and pestle) powder on $3 \mathrm{M}$ tape. We used IFEFFIT software to calibrate the energy scale, correct the background signal and normalize the intensity. The spectra were normalized with respect to the edge height after subtracting the pre-edge and post-edge backgrounds using Athena software. To extract the EXAFS oscillations, the background was removed in k-space using a five-domain cubic spline. The resulting k-space data were then Fourier transformed.

Thermal $\mathrm{CO}_{2}$ methanation test. First, $100 \mathrm{mg}$ of the catalyst was transferred to the reaction cell and pre-reduced at $400{ }^{\circ} \mathrm{C}$ for $2.5 \mathrm{~h}$ under $\mathrm{H}_{2}$ gas $\left(10 \% \mathrm{H}_{2}+90 \%\right.$ Ar) flowing at $100 \mathrm{ml} \mathrm{min}^{-1}$. After cooling to room temperature, the reaction gas, a mixture of $2.5 \% \mathrm{CO}_{2}+10 \% \mathrm{H}_{2}+87.5 \% \mathrm{~N}_{2}$, was introduced. The catalyst was heated to the desired reaction temperature at a heating rate of $5^{\circ} \mathrm{C} \min ^{-1}$. The temperature was detected using a platinum resistance thermometer (M363886). The catalyst was kept at each temperature for $30 \mathrm{~min}$. Then, the composition of the outlet gas was analyzed by an on-line gas chromatograph equipped with a flame ionization detector (FID).

When calculating the turnover frequencies (TOF values), we assumed that all the $\mathrm{Ni}$ in the $\mathrm{SA} \mathrm{Ni} / \mathrm{Y}_{2} \mathrm{O}_{3}$ took part in $\mathrm{CO}_{2}$ methanation. The TOF value for the methanation of $\mathrm{CO}_{2}$ was calculated based on the formula below:

$$
\mathrm{TOF}=\left(V_{\mathrm{CO} 2}^{*} A^{*} 59\right) /\left(\mathrm{Ni}_{\mathrm{a}}^{*} 22.4\right)
$$



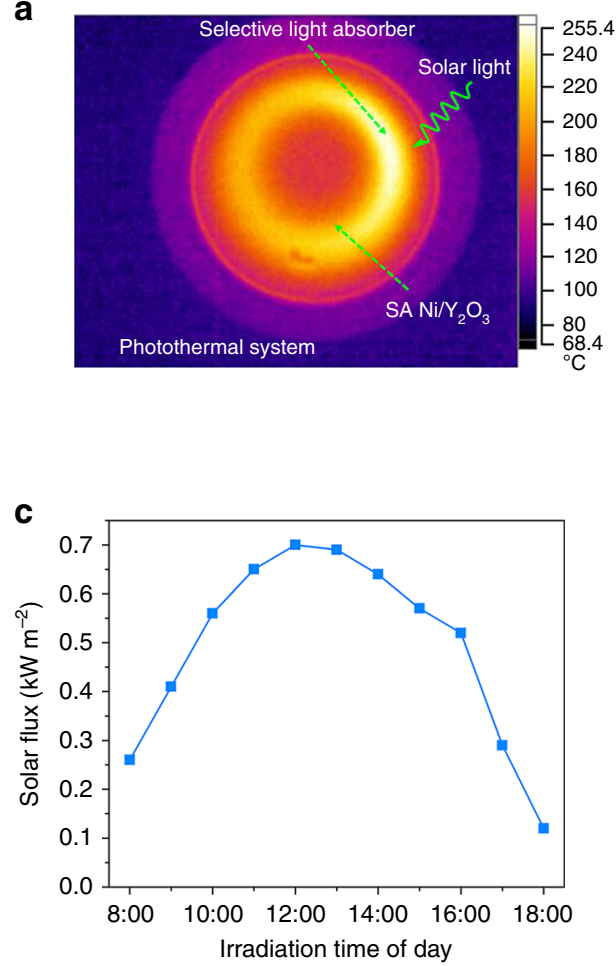
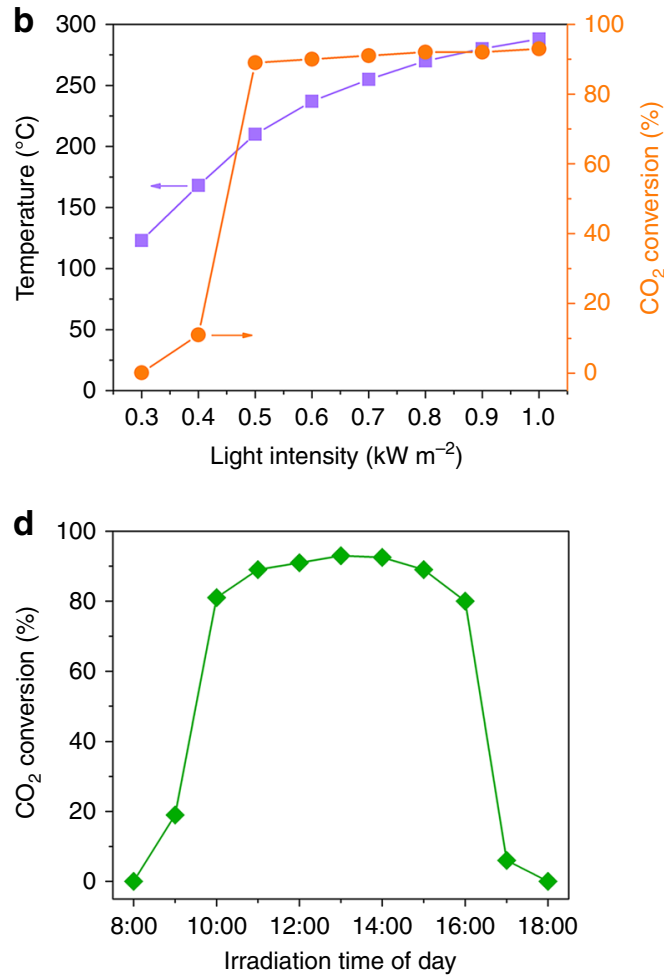

Fig. 5 Photothermal $\mathrm{CO}_{2}$ methanation performance of the $\mathrm{SA} \mathrm{Ni} / \mathrm{Y}_{2} \mathrm{O}_{3}$ nanosheets with a selective light absorber-assisted photothermal system. a Spatial temperature mapping of the selective light absorber-assisted quartz tube coated with the $\mathrm{SA} \mathrm{Ni} / \mathrm{Y}_{2} \mathrm{O}_{3}$ nanosheets under $1.0 \mathrm{~kW}$ m ${ }^{-2}$ of simulated solar irradiation obtained by an infrared camera. $\mathbf{b}$ The temperature and $\mathrm{CO}_{2}$ conversion achieved by the $\mathrm{SA} \mathrm{Ni} / \mathrm{Y}_{2} \mathrm{O}_{3}$ nanosheets with the selective light absorber-assisted photothermal system under different intensities of simulated solar light. c The solar flux over time on June 30, 2018 from 8:00 to 18:00 in Baoding, Hebei, China. d The corresponding photothermal $\mathrm{CO}_{2}$ conversion over the $\mathrm{SA} \mathrm{Ni} / \mathrm{Y}_{2} \mathrm{O}_{3}$ nanosheets with the selective light absorber-assisted photothermal system as a function of time. Reaction conditions: $100 \mathrm{ml} \mathrm{min}{ }^{-1}$ of reaction gas $\left(2.5 \% \mathrm{CO}_{2}+10 \% \mathrm{H}_{2}+87.5 \% \mathrm{~N}_{2}\right), 100 \mathrm{mg}$ of catalyst

where $V_{\mathrm{CO} 2}$ is the $\mathrm{CO}_{2}$ flux $\left(0.042 \mathrm{ml} \cdot \mathrm{S}^{-1}\right), A$ is the $\mathrm{CO}_{2}$ conversion rate, and $\mathrm{Ni}_{a}$ is the quantity of nickel in $\mathrm{SA} \mathrm{Ni} / \mathrm{Y}_{2} \mathrm{O}_{3}(3.9 \mathrm{mg})$.

Optical property. The UV-Vis-IR optical properties of the $\mathrm{Ni} / \mathrm{Y}_{2} \mathrm{O}_{3}$ nanosheets were investigated on a Shimadzu UV3600 UV-Vis spectrophotometer from 300 to $2000 \mathrm{~nm}$. The absorptions in the IR region $(1.5-10 \mu \mathrm{m})$ were detected by an FTIR spectrometer (Bruker, VERTEX 70 FT-IR). The UV-Vis-IR optical properties of the selective light absorber $\left(\mathrm{AlN}_{\mathrm{x}} / \mathrm{Al}\right.$ foil) were provided by Hangzhou Ruijia Precision Science Instrument Co., Ltd.

Temperature detection. The temperatures of all materials were determined by a platinum resistance thermometer (M363886).

Emissivity $(\boldsymbol{\sigma})$ test. IR photographs were taken with a Fluke Ti300 IR camera (America). The emissivity of the $\mathrm{Ni} / \mathrm{Y}_{2} \mathrm{O}_{3}$ nanosheets was tested by an infrared (IR) camera as follows:

First, we heated the sample to the given temperature in a dark environment and measured the temperature of the material with a platinum resistance thermometer. Then, we used an IR camera to measure the temperature of the materials. We changed the emissivity of the IR camera to ensure that the IR temperature was equal to the temperature shown by the thermometer. The emissivity was corrected by factors of 0.93 and 0.95 for the $\mathrm{Ni} / \mathrm{Y}_{2} \mathrm{O}_{3}$ nanosheets at 35 and $200{ }^{\circ} \mathrm{C}$, respectively.

The emissivities of the selective light absorber $\left(\mathrm{AlN}_{\mathrm{x}} / \mathrm{Al}\right.$ foil) were 0.05 and 0.1 at 35 and $200^{\circ} \mathrm{C}$, respectively, which were obtained from the supplier (Hangzhou Ruijia Precision Science Instrument Co., Ltd.).

Light source with selective light absorber. The laboratory light source was an array consisting of six xenon lamps (provided by Hebei Scientist Research Experimental and Equipment Trade Co., Ltd.) equipped with an AM 1.5 -G filter to ensure irradiation covering the whole photothermal system constructed by the selective light absorber, and the light intensity can be tuned by the output current. A foam sheet wrapped in aluminium foil was used to support the tube in the photothermal tests. The light intensity was detected by an irradiance meter (I400).
Light source without selective light absorber. A xenon lamp (Microsolar 300 from PerfectLight) was used to provide 1 sun intensity for the $\mathrm{Ni} / \mathrm{Y}_{2} \mathrm{O}_{3}$ nanosheets. One sun intensity was detected by an irradiance meter (I400).

Calculation of the thermal radiation. The thermal radiation was calculated according to the Stefan-Boltzmann law:

$$
J=\varepsilon \sigma\left(T_{1}^{4}-T_{2}^{4}\right)
$$

$J$ is the thermal radiation energy, $\sigma$ is the emissivity of the material, and $T_{1}$ and $T_{2}$ are $473 \mathrm{~K}\left(20{ }^{\circ} \mathrm{C}\right)$ and $308 \mathrm{~K}\left(35^{\circ} \mathrm{C}\right)$, respectively. According to the $\sigma$ of the Ni/ $\mathrm{Y}_{2} \mathrm{O}_{3}$ nanosheets and the selective light absorber at different temperatures, the thermal radiation generated by the $\mathrm{Ni} / \mathrm{Y}_{2} \mathrm{O}_{3}$ nanosheets and the selective light absorber were 2.27 and $0.21 \mathrm{~kW} \mathrm{~m}^{-2}$, respectively.

Photothermal catalysis tests. The photothermal test of $100 \mathrm{mg}$ of catalyst was conducted as follows: $100 \mathrm{mg}$ of catalyst was transferred to a quartz tube reactor, and then a gaseous mixture of $10 \% \mathrm{H}_{2}-90 \% \mathrm{Ar}\left(100 \mathrm{ml} \mathrm{min}^{-1}\right)$ was fed into the reactor. The temperature was raised to $400^{\circ} \mathrm{C}$ for $2.5 \mathrm{~h}$. After cooling to room temperature under $\mathrm{N}_{2}$, the reaction gas was fed into the reaction vessel at a rate of $100 \mathrm{sccm}$. A gaseous mixture of $2.5 \% \mathrm{CO}_{2}-10 \% \mathrm{H}_{2}-87.5 \% \mathrm{~N}_{2}$ was supplied as the feeding gas. A xenon lamp (Microsolar 300) equipped with an AM 1.5 A G filter was used as the light source. The composition of the outlet gas was analyzed by an on-line gas chromatograph equipped with a flame ionization detector.

Photothermal catalysis test with selective light absorber. To replace the electric heating system with the photothermal system, the reaction tube was coated with the sunlight-selective absorber $\left(\mathrm{AlN}_{\mathrm{x}} / \mathrm{Al}\right.$ foil), as shown in Fig. $1 \mathrm{~g}$ and Supplementary Fig. 3, and this system was used as the light absorber to achieve a high temperature. One hundred milligrams of the sample was used to coat the inner wall of the tube, and then a gaseous mixture of $10 \% \mathrm{H}_{2}-90 \% \mathrm{Ar}\left(100 \mathrm{ml} \mathrm{min}^{-1}\right)$ was fed into the reactor. Then, the tube was irradiated with 2 suns $\left(2 \mathrm{~kW} \mathrm{~m}^{-2}\right)$ to achieve a high temperature for $2.5 \mathrm{~h}$. After cooling to room temperature, the reaction gas, a mixture of $2.5 \% \mathrm{CO}_{2}+10 \% \mathrm{H}_{2}+87.5 \% \mathrm{~N}_{2}$, was introduced. The composition of the outlet gas was analyzed by an on-line gas chromatograph equipped with a flame ionization detector. 
Outdoor catalysis tests. The outdoor tests were similar to the photothermal catalysis tests. The only difference was that ambient sunlight was the light source. The test day was June 30, 2018. formula:

The $\mathrm{CO}_{2}$ methanation rate $(\eta)$ of $7.5 \mathrm{~L} \mathrm{~m}^{-2} \mathrm{~h}^{-1}$ was calculated by the following

$$
\eta\left(\mathrm{Lm}^{-2} \mathrm{~h}^{-1}\right)=K * L * S * 60 / 0.018
$$

$K(=87.9 \%)$ was the average $\mathrm{CO}_{2}$ conversion efficiency from 10:00 to 16:00 (shown in Fig. 5a), $L$ was the gas flow rate $\left(0.1 \mathrm{~L} \mathrm{~min}^{-1}\right), S$ was the ratio of $\mathrm{CO}_{2}$ in the feed gas $(2.10 \%), 60$ was the time $(60 \mathrm{~min})$, and $0.018 \mathrm{~m}^{2}$ was the measured irradiation area.

\section{Data availability}

The data that support the findings of this study are available from the corresponding authors upon reasonable requests.

Received: 14 January 2019 Accepted: 30 April 2019

Published online: 29 May 2019

\section{References}

1. Zhang, Y. et al. Surface-plasmon-driven hot electron photochemistry. Chem. Rev. 118, 2927-2954 (2017).

2. Robatjazi, H. et al. Plasmon-induced selective carbon dioxide conversion on earth-abundant aluminum-cuprous oxide antenna-reactor nanoparticles. Nat. Commun. 8, 27 (2017).

3. Zhao, Y. et al. Two-dimensional-related catalytic materials for solar-driven conversion of $\mathrm{CO}_{\mathrm{x}}$ into valuable chemical feedstocks. Chem. Soc. Rev. 48, 1972-2010 (2019).

4. Rao, H., Schmidt, L. C., Bonin, J. \& Robert, M. Visible-light-driven methane formation from $\mathrm{CO}_{2}$ with a molecular iron catalyst. Nature $\mathbf{5 4 8}$, 74-77 (2017)

5. Ren, J. et al. Targeting activation of $\mathrm{CO}_{2}$ and $\mathrm{H}_{2}$ over Ru-loaded ultrathin layered double hydroxides to achieve efficient photothermal $\mathrm{CO}_{2}$ methanation in flow-type system. Adv. Energy Mater. 7, 1601657 (2017).

6. Gattuso, J. P. et al. Contrasting futures for ocean and society from different anthropogenic $\mathrm{CO}_{2}$ emissions scenarios. Science 349, aac4722 (2015).

7. Chu, S. \& Majumdar, A. Opportunities and challenges for a sustainable energy future. Nature 488, 294 (2012).

8. Shin, H. H., Lu, L., Yang, Z., Kiely, C. J. \& McIntosh, S. Cobalt catalysts decorated with platinum atoms supported on barium zirconate provide enhanced activity and selectivity for $\mathrm{CO}_{2}$ methanation. Acs. Catal. 6, 2811-2818 (2016).

9. Long, X. et al. A strongly coupled graphene and FeNi double hydroxide hybrid as an excellent electrocatalyst for the oxygen evolution reaction. Angew. Chem. Int. Ed. 53, 7584-7588 (2014).

10. Suen, N. T. et al. Electrocatalysis for the oxygen evolution reaction: recent development and future perspectives. Chem. Soc. Rev. 46, 337-365 (2017).

11. Zhang, Y. et al. Rapid synthesis of cobalt nitride nanowires: highly efficient and low-cost catalysts for oxygen evolution. Angew. Chem. Int. Ed. 55, 8670-8674 (2016).

12. Tada, S., Ochieng, O. J., Kikuchi, R., Haneda, T. \& Kameyama, H. Promotion of $\mathrm{CO}_{2}$ methanation activity and $\mathrm{CH}_{4}$ selectivity at low temperatures over $\mathrm{Ru}$ / $\mathrm{CeO}_{2} / \mathrm{Al}_{2} \mathrm{O}_{3}$ catalysts. Int. J. Hydrog. Energ. 39, 10090-10100 (2014).

13. Westermann, A. et al. Insight into $\mathrm{CO}_{2}$ methanation mechanism over NiUSY zeolites: an operando IR study. Appl. Catal. B-Environ. 174, 120-125 (2015).

14. Li, W., Yanhui, Y., Chunfei, W., Hongchen, G. \& Xin, T. One-step reforming of $\mathrm{CO}_{2}$ and $\mathrm{CH}_{4}$ into high-value liquid chemicals and fuels at room temperature by plasma-driven catalysis. Angew. Chem. Int. Ed. 129, 13867-13871 (2017).

15. Hui, H. et al. Solar-light-driven $\mathrm{CO}_{2}$ reduction by $\mathrm{CH}_{4}$ on silica-clustermodified Ni nanocrystals with a high solar-to-fuel efficiency and excellent durability. Adv. Energy Mater. 8, 1702472 (2018).

16. Song, H. et al. Light-enhanced carbon dioxide activation and conversion by effective plasmonic coupling effect of $\mathrm{Pt}$ and Au Nanoparticles. Acs. Appl. Mater. Inter 10, 408-416 (2017)

17. Song, H. et al. Visible-light-mediated methane activation for steam methane reforming under mild conditions: a case study of $\mathrm{Rh} / \mathrm{TiO}_{2}$. Catal. Acs. Catal. 8, 7556-7565 (2018).

18. Liu, G. et al. Elemental boron for efficient carbon dioxide reduction under light irradiation. Angew. Chem. Int. Ed. 56, 5570-5574 (2017).

19. Liu, H. et al. Conversion of carbon dioxide by methane reforming under visible-light irradiation: surface-plasmon-mediated nonpolar molecule activation. Angew. Chem. Int. Ed. 54, 11545-11549 (2015).
20. Meng, $\mathrm{X}$. et al. Photothermal conversion of $\mathrm{CO}_{2}$ into $\mathrm{CH}_{4}$ with $\mathrm{H}_{2}$ over Group VIII nanocatalysts: an alternative approach for solar fuel production. Angew. Chem. Int. Ed. 53, 11478-11482 (2014).

21. Chen, G. et al. Alumina-supported CoFe alloy catalysts derived from layereddouble-hydroxide nanosheets for efficient photothermal $\mathrm{CO}_{2}$ hydrogenation to hydrocarbons. Adv. Mater. 30, 1704663 (2018).

22. Bennie, J., Davies, T. W., Duffy, J. P., Inger, R. \& Gaston, K. J. Contrasting trends in light pollution across Europe based on satellite observed night time lights. Sci. Rep. 4, 3789 (2014).

23. Oara Neumann, A. S. U., Jared Day, Surbhi, Lal, Peter, Nordlander \& Naomi, J. Halas. Solar vapor generation enabled by Nanoparticles.pdf. Acs. Nano. 7, 42-49 (2013).

24. Bae, K. et al. Flexible thin-film black gold membranes with ultrabroadband plasmonic nanofocusing for efficient solar vapour generation. Nat. Commun. 6, 10103 (2015)

25. Zeng, Y., Wang, K., Yao, J. \& Wang, H. Hollow carbon beads for significant water evaporation enhancement. Chem. Eng. Sci. 116, 704-709 (2014).

26. $\mathrm{Xu}, \mathrm{N}$. et al. Mushrooms as efficient solar steam-generation devices. $A d v$. Mater. 29, 201606762 (2017).

27. Wang, J. et al. High-performance photothermal conversion of narrowbandgap $\mathrm{Ti}_{2} \mathrm{O}_{3}$ nanoparticles. Adv. Mater. 29, 201603730 (2017).

28. Wang, Y., Zhang, L. \& Wang, P. Self-floating carbon nanotube membrane on macroporous silica substrate for highly efficient solar-driven interfacial water evaporation. Acs. Sustain. Chem. Eng. 4, 1223-1230 (2016).

29. Meier-Menches, S. M., Gerner, C., Berger, W., Hartinger, C. G. \& Keppler, B. K. Structure-activity relationships for ruthenium and osmium anticancer agents - towards clinical development. Chem. Soc. Rev. 47, 909-928 (2018).

30. Pandey, D. \& Deo, G. Effect of support on the catalytic activity of supported $\mathrm{Ni}-\mathrm{Fe}$ catalysts for the $\mathrm{CO}_{2}$ methanation reaction. J. Ind. Eng. Chem. 33, 99-107 (2016).

31. Qiao, B. et al. Single-atom catalysis of $\mathrm{CO}$ oxidation using $\mathrm{Pt}_{1} / \mathrm{FeO}_{\mathrm{x}}$. Nat. Chem. 3, 634 (2011).

32. Shan, J., Li, M., Allard, L. F., Lee, S. \& Flytzani-Stephanopoulos, M. Mild oxidation of methane to methanol or acetic acid on supported isolated rhodium catalysts. Nature 551, 605-608 (2017).

33. Guo, Y. et al. Low-temperature $\mathrm{CO}_{2}$ methanation over $\mathrm{CeO}_{2}$-supported $\mathrm{Ru}$ single atoms, nanoclusters and nanoparticles competitively tuned by strong metal-support interactions and H-spillover effect. Acs. Catal. 8, 6203-6215 (2018).

34. Kwak, J. H., Kovarik, L. \& Szanyi, J. $\mathrm{CO}_{2}$ reduction on supported $\mathrm{Ru} / \mathrm{Al}_{2} \mathrm{O}_{3}$ catalysts: cluster size dependence of product selectivity. Acs. Catal. 3, 2449-2455 (2013)

35. Younas, M. et al. Recent advancements, fundamental challenges, and opportunities in catalytic methanation of $\mathrm{CO}_{2}$. Energ. Fuel. 30, 8815-8831 (2016).

36. Cao, F., McEnaney, K., Chen, G. \& Ren, Z. A review of cermet-based spectrally selective solar absorbers. Energy Environ. Sci. 7, 1615-1627 (2014).

37. Cao, F. et al. A high-performance spectrally-selective solar absorber based on a yttria-stabilized zirconia cermet with high-temperature stability. Energy Environ. Sci. 8, 3040-3048 (2015).

38. Dao, T. D. et al. Infrared perfect absorbers fabricated by colloidal mask etching of $\mathrm{Al}-\mathrm{Al}_{2} \mathrm{O}_{3}-\mathrm{Al}$ trilayers. Acs. Photonics 2, 964-970 (2015).

39. McEnaney, K., Weinstein, L., Kraemer, D., Ghasemi, H. \& Chen, G. Aerogel based solar thermal receivers. Nano. Energy 40, 180-186 (2017).

40. $\mathrm{Hu}, \mathrm{X}$. et al. Tailoring graphene oxide-based aerogels for efficient solar steam generation under one sun. Adv. Mater. 29, 1604031 (2017).

41. Gao, L. et al. Synthesizing new types of ultrathin 2D metal oxide nanosheets via half-successive ion layer adsorption and reaction. 2D. Mater. 4, 025031 (2017).

42. Zhao, C. et al. Ionic exchange of metal-organic frameworks to access single nickel sites for efficient electroreduction of $\mathrm{CO}_{2}$. J. Am. Chem. Soc. 139, 8078-8081 (2017).

43. Görlin, M. et al. Oxygen evolution reaction dynamics, faradaic charge efficiency, and the active metal redox states of $\mathrm{Ni}-\mathrm{Fe}$ oxide water splitting electrocatalysts. J. Am. Chem. Soc. 138, 5603-5614 (2016).

44. Liu, J. et al. Enhanced low-temperature activity of $\mathrm{CO}_{2}$ methanation over highlydispersed $\mathrm{Ni} / \mathrm{TiO}_{2}$ catalyst. Catal. Sci. Technol. 3, 2627-2633 (2013).

45. Wang, Y., Arandiyan, H., Scott, J., Dai, H. \& Amal, R. Hierarchically porous network-like $\mathrm{Ni} / \mathrm{Co}_{3} \mathrm{O}_{4}$ : noble metal-free catalysts for carbon dioxide methanation. Adv. Sustain. Syst. 2, 1700119 (2018).

46. Muroyama, H. et al. Carbon dioxide methanation over Ni catalysts supported on various metal oxides. J. Catal. 343, 178-184 (2016).

\section{Acknowledgements}

This work is supported by the National Nature Science Foundation of China (Grant No. 51702078, 21633004), Outstanding Youth Foundation of Hebei Province (Grant No. A2016201176), Outstanding Doctoral Cultivation Project of Hebei University (Grant No YB201502), received partial financial support from JSPS KAKENHI Grant Number 
JP18H02065, Photo-excitonix Project in Hokkaido University and State Scholarship Fund by China Scholarship Council (CSC) (No. 201606320239). We acknowledge the Shanghai Synchrotron Radiation Facility (SSRF) for conducting the EXAFS experiment (BL14W1)

\section{Author contributions}

Y.L., S.W., Y.H., and J.Y. conceived the project and contributed to the design of the experiments and analysis of the data. Y.L. and H.S. performed the selective light absorber-assisted photothermal system preparation, characterizations. J.H., F.Z. performed the catalyst preparation, characterizations. Y.L., H.S., J.H., X.M. wrote the paper. X.B., H.Z. conducted the SEM and TEM examinations. All the authors discussed the results and commented on the paper.

\section{Additional information}

Supplementary Information accompanies this paper at https://doi.org/10.1038/s41467019-10304-y.

Competing interests: The authors declare no competing interests.

Reprints and permission information is available online at http://npg.nature.com/ reprintsandpermissions/
Journal peer review information: Nature Communications thanks Jason Scottand the other, anonymous, reviewer(s) for their contribution to the peer review of this work. Peer reviewer reports are available.

Publisher's note: Springer Nature remains neutral with regard to jurisdictional claims in published maps and institutional affiliations.

cc (i) Open Access This article is licensed under a Creative Commons Attribution 4.0 International License, which permits use, sharing, adaptation, distribution and reproduction in any medium or format, as long as you give appropriate credit to the original author(s) and the source, provide a link to the Creative Commons license, and indicate if changes were made. The images or other third party material in this article are included in the article's Creative Commons license, unless indicated otherwise in a credit line to the material. If material is not included in the article's Creative Commons license and your intended use is not permitted by statutory regulation or exceeds the permitted use, you will need to obtain permission directly from the copyright holder. To view a copy of this license, visit http://creativecommons.org/ licenses/by/4.0/.

(C) The Author(s) 2019 